\title{
Infant and Young Child Feeding Practices Among Chepang Community, Chitwan
}

\author{
Iswari Luitel', Rita Kumari Ban² and Sabika Munikar'
}

${ }^{1}$ Om Health Campus, Kathmandu, Nepal

${ }^{2}$ Nepalese Army Institute of Health Sciences, Sanobharyang, Kathmandu, Nepal

\begin{abstract}
Introduction: Infant and young child feeding practices play vital role for the growth and development. It is recommended to exclusively breastfed for first six months and thereafter receive complementary foods with continued breastfeeding. However Chepang, the indigenous community of Nepal depends primarily upon forest food. This study aims to determine the infant and young child feeding practices among Chepang children.

Methods: A cross sectional study was conducted among the mothers of 77 children aged six to 59 months through purposive sampling. Data was collected through face to face interview taking informed written consent. The collected data were analysed for descriptive and bivariate analysis using SPSS version 21.

Results: In this study, mean age of respondents was $25.92( \pm 7.04)$ years, $68.8 \%$ followed Christian religion, $51.9 \%$ were educated, only $45.5 \%$ of respondent's spouse were educated and $51.9 \%$ belonged to nuclear family. Among the respondents, $65.7 \%$ had good breast feeding practice and $88.3 \%$ had good complementary feeding practice. Statistically significant relationship was found between breast feeding practice and educational status and also between complementary feeding practice and family type.

Conclusions: This study found that respondents had good breast feeding practice and complementary feeding practice. Among the respondent, seven out of 10 had good breast feeding practice and nine out of 10 had good complementary feeding practice. Association between breast feeding practice and educational status puts light upon the need for educating and empowering women for improved infant and young child feeding practices.

Key words: breast feeding; complementary feeding; indigenous people; infant and young child; Nepal
\end{abstract}

Correspondence: Sabika Munikar, Om Health Campus, Kathmandu, Nepal. mesabika@gmail.com. E-mail: mesabika@gmail.com.

DOI: http://dx.doi.org/10.3126/mjsbh.v19i1.22813

Submitted on: 2019-02-22

Accepted on: 2019-12-16 


\section{INTRODUCTION}

Right to good nutrition is the right of every infant and child as per the "Convention on the Rights of the Child". ${ }^{1}$ The prevalence of underweight and stunting worldwide remains highest in South East Asia. ${ }^{2}$ Optimal and young child feeding practices rank among the most effective intervention to improve child health. ${ }^{3}$ World Health Organisation (WHO) and United Nations Children's Fund (UNICEF) recommends that infants be exclusively breastfed for the first six months of age and thereafter receive complementary foods in addition to continued breastfeeding until second birthday or beyond. $^{3}$

Nepal Demographic Health Survey (NDHS) 2016 shows that only two among three of children less than six months have been exclusively breast fed. ${ }^{4}$ The Chepang are an indigenous Tibeto-Burman ethnic group mainly inhabiting the rugged ridges of the Mahabharata mountain range of Central Nepal. Historically, Chepang are a tribal group who primitively survive on forest products such as wild fruits, leaves, tubers and roots. Food crisis is a common fate of the Chepang people. ${ }^{5}$ In Nepal, nutritional values of foods also have been suppressed by addition of toxin. ${ }^{6}$ Thus, it is an important task for Chepang mothers to meet the nutritional demands of infant and young children.

The present study aims to determine the infant and young child feeding practices among Chepang mothers of children aged six to 59 months.

\section{METHODS}

A cross sectional study was conducted among the mothers of 77 children aged six to 59 months residing at Chepang community of Chitwan through purposive sampling. Data was collected through face to face interview using semi structured questionnaire on March to April, 2019 by principal investigator. Content validity and consistency of the tool was maintained through the use of pretested questionnaire among 10 participants of similar community in Chitwan. Ethical approval was obtained from Nepal Health Research Council (Ref \#2579, 25 ${ }^{\text {th }}$ March 2019) prior to data collection.
All the respondents were briefed about the study and written informed consent was obtained. The collected data were checked for completeness, entered in Microsoft Excel, then exported to Statistical Package for Social Science (SPSS version 21) for further processing and analysis. The descriptive statistics and bivariate analysis were done and presented in tables. The breast feeding and complementary practice was categorised as good or poor practice based on mean score of questions related to breast feeding and complementary feeding respectively. The score equal to or greater than mean denotes good practice and less than mean denotes poor practice.

\section{RESULTS}

Table 1 depicts the demographic characteristics of respondents. Among the total respondents, mean age was $25.92( \pm 7.04)$ years. Higher number of respondent $(61 \%)$ were 20 to 35 years of age, followed Christian religion (68.8\%) and more than half of the respondents $(51.9 \%)$ were educated. Almost all the respondents were homemakers. Only $45.5 \%$ of respondent's spouse were educated. Almost half of the respondents (51.9\%) belonged to nuclear family.

Table 2 reveals the obstetric history of respondent. The average number of children given birth by the respondents was two. Almost half of the respondent's children (48.1\%) belonged to age nine to 24 months. More than half of the respondent's children $(57.1 \%)$ were males. Majority of respondents $(80.5 \%)$ gave birth to child at home. Most of the respondents (94.8\%) gave birth via Spontaneous Vaginal Delivery (SVD) and remaining via Lower Segment Caesarean Section (LSCS) (5.2\%).

Table 3 depicts the respondent's breastfeeding practices. Almost all the respondents (98.7\%) breast fed at some point of time. Only half of the respondents $(52.7 \%)$ breast fed their child within 60 minutes of birth. All the breast fed children were fed colostrum. Among the respondents, $6.5 \%$ gave prelacteal feed to the baby. The types of prelacteal feed given were honey, rice, lactogen and wine. Only $1.3 \%$ respondent's breast fed from one breast 
Table 1. Distribution of socio-demographic characteristics of respondents $(n=77)$

\begin{tabular}{|c|c|c|}
\hline Characteristics & Frequency & Percent (\%) \\
\hline \multicolumn{3}{|c|}{ Age of children (years)* } \\
\hline$<20$ & 21 & 27.3 \\
\hline $20-35$ & 47 & 61.0 \\
\hline$>35$ & 9 & 11.7 \\
\hline \multicolumn{3}{|l|}{ Religion } \\
\hline Christian & 53 & 68.8 \\
\hline Hindu & 16 & 20.8 \\
\hline Buddhist & 8 & 10.4 \\
\hline \multicolumn{3}{|c|}{$\begin{array}{l}\text { Mother's educational } \\
\text { status }\end{array}$} \\
\hline Educated & 40 & 51.9 \\
\hline Uneducated & 37 & 48.1 \\
\hline \multicolumn{3}{|c|}{$\begin{array}{l}\text { Spouse's educational } \\
\text { status }\end{array}$} \\
\hline Educated & 35 & 45.5 \\
\hline Uneducated & 42 & 54.5 \\
\hline \multicolumn{3}{|l|}{ Type of family } \\
\hline Nuclear & 40 & 51.9 \\
\hline Joint & 37 & 48.1 \\
\hline
\end{tabular}

*Mean- 25.92 ( \pm 7.04$)$

at a time. Respondents who breastfed for less than 10 minutes was higher i.e. $63.6 \%$.

Less than half of the respondents $(42.9 \%)$ breast fed exclusively for less than six months. The number of breast feeding among children aged six to nine months during day was less than 10 $(31.2 \%)$. Similarly, the number of breastfeeding times during the night was less than two among half of the respondents i.e. $53.3 \%$. Also, the number of breastfeeding during day among respondents with children nine to 12 months was less than 10 among $25 \%$ of respondents. Similarly, number of night feeds was more than two among all respondents.

Table 4 depicts the complementary feeding practices among respondents. Less than half of respondents $(44.6 \%)$ started complementary feeding before six months of age. Most of the
Table 2. Distribution of respondent according to obstetric history $(n=77)$

\begin{tabular}{|c|c|c|}
\hline Characteristics & Frequency & Percent (\%) \\
\hline \multicolumn{3}{|l|}{ Number of children* } \\
\hline$<2$ & 37 & 48.1 \\
\hline $3-4$ & 33 & 42.9 \\
\hline$>4$ & 7 & 9.0 \\
\hline \multicolumn{3}{|l|}{$\begin{array}{l}\text { Age of last child } \\
\text { (months) }\end{array}$} \\
\hline $6-9$ & 16 & 20.8 \\
\hline $9-24$ & 37 & 48.0 \\
\hline $24-60$ & 24 & 31.2 \\
\hline \multicolumn{3}{|l|}{ Sex of child } \\
\hline Male & 44 & 57.1 \\
\hline Female & 33 & 42.9 \\
\hline \multicolumn{3}{|l|}{ Place of delivery } \\
\hline Home & 62 & 80.5 \\
\hline Hospital & 15 & 19.5 \\
\hline \multicolumn{3}{|l|}{ Type of delivery } \\
\hline $\begin{array}{l}\text { Spontaneous Vaginal } \\
\text { Delivery (SVD) }\end{array}$ & 73 & 94.8 \\
\hline $\begin{array}{l}\text { Lower Segment Cesarean } \\
\text { Section (LSCS) }\end{array}$ & 4 & 5.2 \\
\hline
\end{tabular}

*Average- 2, Minimum-1, Maximum-9

respondents (92.2\%) continued breastfeeding along with complementary feeding. Majority of respondents $(75 \%)$ with child six to nine months fed solid/semi solid food two times a day and remaining $25 \%$ fed three times a day. The types of complementary food used were vegetables, water, pulses, meat and others. Majority of the respondents fed snack i.e. $71.6 \%$. The type of snacks fed were dhido, rice, jaulo and other. Very few respondents fed super flour to the child i.e. $5.5 \%$. Among them, majority (75\%) prepared super flour at home.

Table 5 depicts the respondents' cultural taboos regarding feeding. Very few respondents i.e. 9.1\% had misconception of not giving particular food. The type of food avoided were vegetables $(85.7 \%)$ followed by wine, pulses and dhido (14.3\% each). 
Table 3. Distribution of Respondents according to Breast Feeding Practices $(n=77)$

\begin{tabular}{|l|r|r|}
\hline Characteristics & Frequency & Percent(\%) \\
\hline Ever breast fed & 76 & 98.7 \\
\hline Time of first breast feeding $(\mathrm{n}=74)$ & 39 & 52.7 \\
\hline$<60$ minutes & 76 & 100.0 \\
\hline $\begin{array}{l}\text { Colostrum feeding } \\
\text { (n=76) }\end{array}$ & 5 & 6.5 \\
\hline Prelacteal feeding & 2 & 40 \\
\hline Type of prelacteal feed (n=5) & 1 & 20 \\
\hline Honey & 1 & 20 \\
\hline Rice & 1 & 20 \\
\hline Lactogen & 1 & 1.3 \\
\hline Wine & & \\
\hline Breast feed from single \\
breast at a time
\end{tabular}

Number of breast feeding during day among six to nine months $(n=16)$

$$
>10 \text { and more }
$$

Number of night feeds among six to nine months $(\mathrm{n}=15)$

$$
>2 \text { and more }
$$$$
7
$$

Number of breast feeding during day among nine to 12 months $(n=4)$

$$
>10 \text { and more } 3
$$

Number of breast feeding during night among nine to 12 months $(n=4)$

$$
>2 \text { and more time feeds }
$$

4 among 9-24 months

The reasons for avoiding particular food were greenish stool, stomach ache followed by others. Most of the respondents practiced breastfeeding during the child illness and self-illness i.e. $98.7 \%$ respectively.
Table 4. Distribution of respondents according to complementary feeding practices $(n=74)$

\begin{tabular}{|l|r|r|}
\hline Characteristics & Frequency & $\begin{array}{l}\text { Percent } \\
(\%)\end{array}$ \\
\hline $\begin{array}{l}\text { Initiation of } \\
\text { complementary feeding } \\
\text { (<6 months) }\end{array}$ & 33 & 44.6 \\
\hline $\begin{array}{l}\text { Continuation of breast } \\
\text { feeding along with } \\
\text { complementary Feed }(\mathrm{n}=72)\end{array}$ & 71 & 92.2 \\
\hline
\end{tabular}

No. of solid and semi-solid food for six to eight months child

\begin{tabular}{|r|r|r|}
\hline 2 times & 12 & 75 \\
\hline 3 times & 4 & 25 \\
\hline
\end{tabular}

\section{Complementary foods items*}

\begin{tabular}{|l|r|r|}
\hline Vegetables & 68 & 91.9 \\
\hline Water & 12 & 16.2 \\
\hline Pulses & 9 & 12.2 \\
\hline Meat & 6 & 8.1 \\
\hline Other & 8 & 10.8 \\
\hline Snack feeding (n=74) & 53 & 71.6 \\
\hline
\end{tabular}

Type of snack $(n=53)$

\begin{tabular}{|l|r|r|}
\hline Dhido & 30 & 58.8 \\
\hline Rice & 23 & 45.1 \\
\hline Jaulo & 19 & 37.3 \\
\hline Others (Chowchow, Biscuit) & 3 & 9.8 \\
\hline Super flour (n=73) & 4 & 5.5 \\
\hline Place of super flour supply (n=4) & & \\
\hline Homemade & 3 & 75 \\
\hline Health post & 1 & 25 \\
\hline
\end{tabular}

Table 6 depicts that among 67 respondents, 44 $(65.7 \%)$ had good breast feeding practice while 23 (34.3\%) had poor breast feeding practice. The mean breast feeding practice score was $5.92( \pm 1.15)$. Among 60 respondents, $53(88.3 \%)$ had good complementary feeding practice while $7(11.7 \%)$ had poor practice. The mean practice score was $6.58( \pm 0.93)$.

Table 7 depicts the association between breast feeding practice and selected characteristics. Educational status of respondent was found to be 
Table 5. Distribution of respondents according to cultural taboos regarding feeding $(n=77)$

\begin{tabular}{|l|r|r|}
\hline \multicolumn{2}{|l|}{ Fraracteristics } & $\begin{array}{l}\text { Percent } \\
(\%)\end{array}$ \\
\hline $\begin{array}{l}\text { Have culture of not giving } \\
\text { any food type }\end{array}$ & 7 & 9.1 \\
\hline $\begin{array}{l}\text { Type of food avoided for } \\
\text { baby (n=7) }\end{array}$ & 6 & 85.7 \\
\hline \begin{tabular}{l} 
Vegetable \\
\hline Wine
\end{tabular} & 1 & 14.3 \\
\hline \begin{tabular}{l} 
Pulses \\
\hline Dhido
\end{tabular} & 1 & 14.3 \\
\hline $\begin{array}{l}\text { Reasons for avoiding } \\
\text { particular food (n=7) }\end{array}$ & 1 & 14.3 \\
\hline \begin{tabular}{l} 
Greenish stool \\
\hline Stomachache
\end{tabular} & 4 & 66.7 \\
\hline $\begin{array}{l}\text { Others (Low immunity, } \\
\text { dryness, muscle pain) }\end{array}$ & 76 & 33.3 \\
\hline $\begin{array}{l}\text { Breastfeed during child } \\
\text { illness }\end{array}$ & 3 & 50.6 \\
\hline $\begin{array}{l}\text { Breastfeed during self- } \\
\text { illness }\end{array}$ & 76.7 \\
\hline
\end{tabular}

associated with the breast feeding practice $(p<0.05)$. No any association was found between breast feeding practice and other demographic characteristics.

Table 8 illustrates the association between complementary feeding and selected sociodemographic characteristics. There was association found between complementary feeding and type of family $(p<0.028)$. However, no any association was found with other characteristics.

\section{DISCUSSION}

In this study, the mean age of respondents was 25.92 years which is similar to another study of Nepal where the mean age of respondents was 23.18 years. $^{7}$ It was also seen that $70 \%$ followed Christian religion. Almost half of the respondents were educated however another similar study of Bangladesh found that only 13.6 percent were uneducated $^{8}$ however 60 percent were literate in Bhutan. ${ }^{9}$ Almost all respondents were homemaker which is similar to that of Bangladesh $(91.8 \%)^{8}$
Table 6. Distribution of respondent's breast feeding and complementary feeding practices

\begin{tabular}{|c|c|c|}
\hline $\begin{array}{l}\text { Infant and Young Child } \\
\text { Feeding Practice }\end{array}$ & Frequency & $\begin{array}{l}\text { Percent } \\
(\%)\end{array}$ \\
\hline \multicolumn{3}{|l|}{$\begin{array}{l}\text { Breast feeding practices* } \\
(n=67)\end{array}$} \\
\hline Good practice & 44 & 65.7 \\
\hline Poor practice & 23 & 34.3 \\
\hline \multicolumn{3}{|l|}{$\begin{array}{l}\text { Complementary feeding } \\
\text { practices } * *(n=60)\end{array}$} \\
\hline Good practice & 53 & 88.3 \\
\hline Poor practice & 7 & 11.7 \\
\hline
\end{tabular}

however the finding is different among Satar community of Nepal where 69.7 percent worked as a daily labor. ${ }^{10}$ It was also seen that more than half of husbands were uneducated whereas studies conducted in Bangladesh ${ }^{8}$ and Delhi, India ${ }^{11}$ illustrated that 13.6 percent and 37.5 percent were uneducated respectively. Nuclear family type was found similar to study of Bangladesh. ${ }^{8}$

The average number of children given birth by the respondents were two. Study from Bangladesh reported $69.3 \%$ had less than two children. ${ }^{8}$ Almost half of the respondent's children belonged to age nine to 24 months which is different in Ethiopia i.e. three out of 10 belonged to nine to 11 months. ${ }^{12}$ Six out of 10 children of respondents were males which is different from the study conducted in Bangladesh $^{8}$ and Bhutan ${ }^{9}$ where almost half of the respondent's children were males, it is however similar $(61.3 \%)$ to a study conducted in Chapagaun VDC of Nepal. ${ }^{13}$ Home delivery was found among 80.5 percent and is different from Satar community where home delivery was $60 \% .{ }^{10}$ SVD was found among 94.8 percent which is similar in Chapagaun $\operatorname{VDC}(75.8 \%){ }^{13}$

Almost all babies were breast fed and finding is similar to Ethiopia, ${ }^{12} \mathrm{Nepal}^{7}$ and Bhutan. ${ }^{9}$ Among the respondents, $60 \%$ had breast fed within 60 minutes of birth which is similar with Satar community, Nepal ${ }^{10}$ and an Indian study. ${ }^{14}$ It is 
Table 7. Association between breast feeding practice and selected characteristics $(n=77)$

\begin{tabular}{l|l|l|l|l|}
\hline $\begin{array}{l}\text { Socio } \\
\text { demographi }\end{array}$ & \multicolumn{2}{l|}{ Breast feeding practice } & $\begin{array}{l}\text { Chi- } \\
\text { square }\end{array}$ & v- \\
c & Poor & Good & $\begin{array}{l}\text { sque } \\
\text { value }\end{array}$ & \\
characteristi & frequency & frequency & & \\
cs & $(\%)$ & $(\%)$ & \\
\end{tabular}

\section{Age (in years)}

\begin{tabular}{l|l|l|l|l|}
\hline$<20$ & $5(27.8 \%)$ & $\begin{array}{l}13 \\
(72.2 \%)\end{array}$ & 0.468 & 0.494 \\
\hline$>20$ & $\begin{array}{l}18 \\
(36.7 \%)\end{array}$ & $\begin{array}{l}31 \\
(63.3 \%)\end{array}$ & & \\
& $(36)$ & & \\
\hline
\end{tabular}

\section{Religion}

\begin{tabular}{|c|c|c|c|}
\hline Christian & $\begin{array}{l}16 \\
(34.8 \%)\end{array}$ & $\begin{array}{l}30 \\
(65.2 \%)\end{array}$ & \multirow[t]{2}{*}{0.013} \\
\hline $\begin{array}{l}\text { Others } \\
\text { (Hindu, } \\
\text { Buddhist) }\end{array}$ & $7(33.3 \%)$ & $\begin{array}{l}14 \\
(66.7 \%)\end{array}$ & \\
\hline
\end{tabular}

\section{Educational status}

\begin{tabular}{|l|l|l|l|l|} 
Uneducated & $\begin{array}{l}15 \\
(46.9 \%)\end{array}$ & $\begin{array}{l}17 \\
(53.1 \%)\end{array}$ & 4.277 & 0.039 \\
\hline Educated & $8(22.9 \%)$ & $\begin{array}{l}27 \\
(77.1 \%)\end{array}$ & & \\
& & & \\
\hline
\end{tabular}

\section{Spouse's educational status}

\begin{tabular}{|l|l|l|l|l|}
\hline Uneducated & $\begin{array}{l}14 \\
(38.9 \%)\end{array}$ & $\begin{array}{l}22 \\
(61.1 \%)\end{array}$ & 0.718 & 0.397 \\
\hline Educated & $9(29 \%)$ & $22(71 \%)$ & & \\
\hline
\end{tabular}

\section{Family type}

\begin{tabular}{|l|l|l|l|l|} 
Nuclear & $\begin{array}{l}13 \\
(37.1 \%)\end{array}$ & $\begin{array}{l}22 \\
(62.9 \%)\end{array}$ & 0.257 & 0.612 \\
\hline Joint & 10 & 22 & & \\
& $(31.2 \%)$ & $(68.8 \%)$ & & \\
\hline
\end{tabular}

\section{Number of living children}

\begin{tabular}{|l|l|l|l|l|} 
& $3(16.7 \%)$ & $\begin{array}{l}15 \\
(83.3 \%)\end{array}$ & 3.735 & 0.155 \\
\hline 2 & $6(42.9 \%)$ & $8(57.1 \%)$ & & \\
\hline$>3$ & $14(40 \%)$ & $21(60 \%)$ & & \\
\hline
\end{tabular}

\section{Place of delivery}

\begin{tabular}{|l|l|l|l|l|} 
Home & $\begin{array}{l}18 \\
(32.7 \%)\end{array}$ & $\begin{array}{l}37 \\
(67.3 \%)\end{array}$ & 0.341 & 0.559 \\
\hline Hospital & $5(41.7 \%)$ & $7(58.3 \%)$ & & \\
\hline
\end{tabular}

slightly greater in the study conducted in Chapagaun VDC, Nepal (72.6\%), ${ }^{13}$ even higher in Bhutan $^{9}$ and Bangladesh ${ }^{8}$ i.e. $78 \%$ and $78.3 \%$ respectively. It may be due urban setting $\&$ health
Table 8. Association between complementary feeding and selected characteristics $(n=77)$

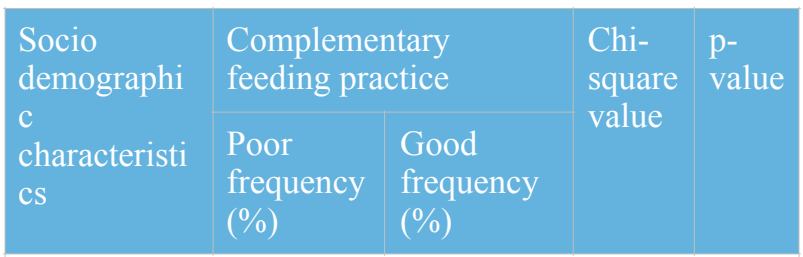

\begin{tabular}{|l|l|l|l|l|}
\multicolumn{2}{|l}{ Age (in years) } \\
\hline$<20$ & $1(8.3 \%)$ & $11(91.7 \%)$ & 0.174 & 0.688 \\
\hline$>20$ & $6(12.5 \%)$ & $42(87.5 \%)$ & & \\
\hline
\end{tabular}

\section{Religion}

\begin{tabular}{|l|l|l|l|l|} 
Christian & $3(7.3 \%)$ & $38(92.7 \%)$ & 2.206 & 0.137 \\
$\begin{array}{l}\text { Others } \\
\text { (Hindu, } \\
\text { Buddhist) }\end{array}$ & $4(21.1 \%)$ & $15(78.9 \%)$ & & \\
\hline
\end{tabular}

\section{Educational status}

\begin{tabular}{|l|l|l|l|l|}
\hline Uneducated & $4(12.9 \%)$ & $27(87.1 \%)$ & 0.096 & 0.757 \\
\hline Educated & $3(10.3 \%)$ & $26(89.7 \%)$ & & \\
\hline
\end{tabular}

\section{Spouse's educational status}

\begin{tabular}{|l|l|l|l|l|}
\hline Uneducated & $6(17.1 \%)$ & $29(82.9 \%)$ & 2.760 & 0.097 \\
\hline Educated & $1(4 \%)$ & $24(96 \%)$ & & \\
\hline
\end{tabular}

\section{Family type}

\begin{tabular}{|l|l|l|l|l|}
\hline Nuclear & $6(20.7 \%)$ & $23(79.3 \%)$ & 4.823 & 0.028 \\
\hline Joint & $1(3.2 \%)$ & $30(96.8 \%)$ & & \\
\hline
\end{tabular}

\section{Number of living children}

\begin{tabular}{|l|l|l|l|l|}
\hline 1 & $1(6.7 \%)$ & $14(93.3 \%)$ & 0.783 & 0.401 \\
\hline 2 & $1(9.1 \%)$ & $10(90.9 \%)$ & & \\
\hline$>3$ & $5(14.7 \%)$ & $29(85.3 \%)$ & & \\
\hline
\end{tabular}

\section{Place of delivery}

\begin{tabular}{|l|l|l|l|l|}
\hline Home & $5(10.6 \%)$ & $42(89.4 \%)$ & 0.210 & 0.647 \\
\hline Hospital & $2(15.4 \%)$ & $11(84.6 \%)$ & & \\
\hline
\end{tabular}

institution based studies thus, might contribute to early initiation of breastfeeding. It shows relatively more proportion than similar study from Nepal. ${ }^{7}$ The observed difference might be due to the high proportion of home delivery in Rupandehi. However, NDHS 2016 presents finding of 55\% under age two are breastfed within an hour of birth. ${ }^{4}$

All of the breast fed child were fed colostrum and is similar to the study of Bangladesh $(88.3 \%)^{8}$ and 
Bhutan $(95 \%)^{9}$ however it is lesser in Rupandehi, Nepal which shows that only half of children fed colostrum. $^{7}$ Superstitious belief that colostrum is harmful for newborn babies might prevail in rural areas and contribute to low colostrum fed. Among the respondents, only $6.5 \%$ gave prelacteal feed to the newborn and shows difference to the study conducted at Bangladesh which showed 19.1\% and in Bhutan four percent practiced it. ${ }^{9}$ The higher literacy rate in Bhutan may be the reason for less prelacteal feeding. ${ }^{9}$ As per NDHS 2016, 29 percent children were given pre lacteal food within three days of birth. ${ }^{4}$ The types of prelacteal feed given were honey, rice, lactogen and wine whereas cow's milk was preferred as prelacteal feed in Satar community. ${ }^{10}$

Exclusive breast feeding for at least six months was practiced among $50.6 \%$ of respondent only which is different to findings from NDHS 2016 with 66\% children being exclusively breast fed for six months and study conducted in Chapagaun where $61.3 \%$ practiced exclusive breast feeding ${ }^{13}$ and $56.2 \%$ in Delhi. ${ }^{11}$ This might be due to higher literacy level and availability of information in these areas than the Chepang community.

Half of respondents started complementary feeding after six months of age. The finding may be due to existing practice throughout Nepal to wean babies at five months for girls and six months for boys. ${ }^{15}$ Breast feeding was continued among $92.2 \%$ of respondents along with complementary feeding. Majority of respondents with child six to eight months fed solid/ semi solid food twice a day i.e. $75 \%$ and remaining $25 \%$ fed thrice a day which is different from Satar community where it was eighty percent. ${ }^{10}$

It was found that $65.7 \%$ had good breast feeding practice and $88.3 \%$ had good complementary feeding practice. This finding is different from another study of Nepal which depicted that although breast feeding practices were good, complementary feeding was found to be poor. $^{13}$

An association between exclusive breastfeeding practice and educational status was found which is similar to a study conducted in Satar community. This similarity may be due to indigenous nature of both community. Furthermore, an association with exclusive breastfeeding practice was found with other characteristics as well such as age, place of delivery, sex of child and number of children which was not found in present study. ${ }^{9}$ The association could not be found in this study probably due to limited participants.

\section{CONCLUSIONS}

This study concludes that respondent had good breast feeding practice and complementary feeding practice. Among the respondents, seven out of 10 had good breast feeding practice and nine out of 10 had good complementary feeding practice. Association between breast feeding practice and educational status puts light upon the need for educating and empowering women for improved infant and young child feeding practices.

To cite this article: Luitel I, Ban RK, Munikar S. Infant and young child feeding practices among Chepang community, Chitwan. MJSBH. 2019;19(1):31-8.

Conflict of Interest: None declared

\section{REFERENCES}

1. World Health Organisation (WHO). Infant and young child feeding [Internet]. Fact sheet. 2018. Available from: https://www.who.int/news-room/fact-sheets/detail/infant-and-young-child-feeding

2. World Health Organisation (WHO). Global and regional trends by WHO regions, 1990- 2025 [Internet]. 2018. Available from: http://apps.who.int/gho/data/node.main.NUTWHOREGIONS?lang=en 
3. WHO. Infant and young child feeding [Internet]. 2009. 1-81 p. Available from: https://www.ncbi.nlm.nih.gov/books/NBK148965/pdf/Bookshelf_NBK148965.pdf

4. Ministry of Health N, New Era, ICF. Nepal Demographic Health Survey. Kathmandu, Nepal; 2017.

5. RSS. Food crisis hits Chepangs hard. The Himalayan Times [Internet]. 2018 May 28. Available from: https://thehimalayantimes.com/nepal/food-crisis-hits-chepangs-hard/

6. Thapa K, Pant BR. Pesticides in vegetable and food commodities : environment and public health concern. J Nepal Heal Res Counc. 2014;12(28):208-10. PMID: 26032063

7. Shah S, Simoes JAR. Breastfeeding and infant / young child feeding in Nepal. Int J Community Med Public Heal. 2019;6(1):51-6. DOI: http://dx.doi.org/10.18203/2394-6040.ijcmph20185226

8. Saizuddin M, Hasan SM, Islam RM, Alfazzaman M, Rahman MM, Rahman MR. Infant and young child feeding ( IYCF ) practices by rural mothers of Bangladesh. JNINB. 2017;2(1):1-5. DOI: $10.3329 /$ medtoday.v28i1.30959

9. Campbell RK, Aguayo VM, Kang Y, Dzed L, Joshi V, Waid J, et al. Infant and young child feeding practices and nutritional status in Bhutan. Matern Child Nutr. 2018;14(S4:e12762):1-6. DOI: https://doi.org/10.1111/mcn.12762

10. Ban R, Rajbanshi L. Infant and young child feeding practices among mothers in Satar community. J Chitwan Med Coll. 2016;6(17):1-7.

Available from: www.jcmc.cmc.edu.np

11. Gupta A, Chhabra P. Infant and young child feeding practices and its determinants in an urbanized village of Delhi. Int J Med Public Heal. 2015;5(3):228-31.

DOI: $10.4103 / 2230-8598.161536$

12. Berra WG, Yang N. Determinants of suboptimal complementary feeding practices among children aged 6-23 months in selected urban slums of Oromia Zones. J Nutr Food Sci. 2017;7(3):1-10. DOI: $10.4172 / 2155-9600.1000593$

13. Basnet D. Infant and Young Child Feeding Practices among Mothers at Chapagaun VDC. Nepal Heal Res Counc. 2016;14(33):116-21.

DOI: https://doi.org/10.33314/jnhrc.v14i2.800

14. Chebrolu K, Budimelli S. Infant and young child feeding practices in Guntur district - A cross sectional study. J Evid Based Med Heal. 2015;2(56):8834-7. DOI: $10.18410 /$ jebmh/2015/1238

15. Dhital SK. Annaprashan/ Pasni (First Rice Feeding Ceremony) [Internet]. Rural Tourism and Environment Development Nepal. 2015 [cited 2019 Sep 23].

Available from: https://skrisshphoolbari.wordpress.com/2015/10/26/annaprashanpasni-first-rice-feeding-ceremony/ 